\title{
sopro da palavra
}

https://doi.org/10.34112/2317-0972a2021V39n83pg-10

\section{Alda Regina Tognini Romaguera \\ Marcus Pereira Novaes \\ Alan Victor Pimenta}

Procuro o sopro da palavra que dá vida aos sussurros

Clarice Lispector

RECORREMOS À PROSA POÉTICA DE LISPECTOR TRAZENDO SEU SOPRO DA palavra que vivifica sussurros, como modo de reafirmar nossa escolha pela vida nesses tempos necropolíticos. Com ela, sopramos estas palavras.

Com o vol. 39, $\mathrm{n}^{\circ} .83$, esta Revista encerra o ano de 2021 publicando seis artigos em demanda contínua, um ensaio, duas resenhas e uma sessão que homenageia Paulo Freire, patrono da educação brasileira. As comemorações de seu centenário nos convidaram a buscar por sua presença na Leitura: Teoria \& Prática, e Davina Marques dedicou-se a esta tarefa, organizando uma sessão que dialoga com o pensamento freiriano e com alguns de seus leitores e estudiosos.

Registramos neste editorial uma outra comemoração, pois neste ano festejamos os 40 anos da Associação de Leitura do Brasil (ALB) e os belos encontros proporcionados aos seus associados e aos amigos da leitura e da escrita. Organizar o Congresso de Leitura do Brasil (COLE) a cada dois anos, publicar as Revistas LT\&P e Linha Mestra, realizar projetos dos núcleos de leitura e formação, manter uma livraria, são algumas das atribuições da ALB. Sopros... sussurros vivos. 
Desejamos vida longa a esta Associação que, a quatro décadas, resiste e divulga diferentes perspectivas de escrita e leitura, reafirmando a luta pela democratização e acesso ao pensamento literário.

A capa desta edição, criada pelo artista Crispim Campos, convoca-nos a habitar um intervalo onde nossa percepção se revela e se desvela continua e intensivamente, como que a nos provocar a suspender falas habituais e palavras de ordem, para que adentremos no tempo do pensamento, na atmosfera das sensações.

Desafia nossos olhos a sentir diferentemente, provoca-os a tocar a imagem, a habitar suas cores e contornos. Essa imagem, em tons de azul e branco, instiga não apenas nosso olhar a um devir tátil, mas, ao ser desafiado - pela figura de uma mulher que paira no centro da imagem, modulando-se em uma íntima relação com o fundo da tela - pode abrir uma possível narrativa que se faz junto com essa arte. A percepção de seu nariz e lábios encobertos pela máscara, com apenas os olhos a mostra - muito abertos, assustados - acompanha-nos como que a indagar: e agora? Ou talvez, a pergunta silenciosa que ouvimos, possa nos convidar a entender um por quê!? Ou um ainda?! Ou seria um outra vez!? Como encarar essa mulher, estética e politicamente, frente aos acontecimentos do agora?

Clarice parece nos responder com mais indagações:

"Escrever" existe por si mesmo? Não. É apenas o reflexo
de uma coisa que pergunta. Eu trabalho com o inesperado.
Escrevo como escrevo sem saber como e por quê - é por
fatalidade de voz. O meu timbre sou eu. Escrever é uma
indagação. É assim?

Os textos aqui publicados têm a potência de abrir um pequeno intervalo em nossa cotidianidade, possibilitar-nos novas aprendizagens e outras percepções entre escutas e olhares, instigando-nos a pensar pelas forças das palavras.

Desejamos a todas e todos uma ótima leitura!! 